\title{
WCZESNOŚREDNIOWIECZNE GRODZISKO WKLĘSŁE W BNINIE KOŁO POZNANIA W ŚWIETLE DOTYCHCZASOWYCH USTALEŃ DENDROCHRONOLOGICZNYCH
}

\author{
EARLY MEDIEVAL STRONGHOLD \\ IN BNIN NEAR POZNAŃ \\ IN THE LIGHT OF DENDROCHRONOLOGY
}

\author{
Michat Kara \\ Instytut Archeologii i Etnologii PAN - Oddział Poznański \\ ul. Zwierzyniecka 20,60-814 Poznań, Poland \\ Maciej Przybyt \\ Muzeum Archeologiczne \\ ul. Wodna 27, 61-781 Poznań, Poland
}

\begin{abstract}
The article presents results of dendrochronological investigations of wooden constructions of the rampart of early medieval stronghold in Bnin (current location Kórnik-Bnin), of which a well preserved stone-wooden-earthen fortifications are among the best recognized in Wielkopolska. The site was excavated in the years 1961-1969. The relicts of two phases of the rampart construction discovered in so-called northem trench were dated to the end of the $12^{\text {th }}$ - beginning of the $13^{\text {th }}$ century. Based on results of dendrochronological dates of 25 samples taken in 1994, a discovered part of the rampart was constructed in two phases with a break in the year 939. The older construction was finished in 938 , while the younger one in 940 .
\end{abstract}

Omawiane badania zostały przeprowadzone w ramach programu weryfikacji metodą dendrochronologiczną datowań średniowiecznych grodzisk wielkopolskich, których metryki ustalono (głównie w ostatnim półwieczu) na podstawie analizy stratygraficznej i/lub porównawczo-typologicznej znalezisk. Akcję podjęto w latach 1990-1992 z inicjatywy Pracowni Wczesnośredniowiecznej Instytutu Archeologii i Etnologii PAN w Poznaniu, planując ją w skali regionu jako dłuższy cykl badawczy. Juź pierwsze rezultaty - rewelacyjne poznawczo - przesądziły o kontynuacji programu do chwili obecnej, głównie siłami wymienionej Pracowni, jednak przy wydatnej współpracy wielkopolskich placówek muzealnych (zwłaszcza poznańskiego Muzeum Archeologicznego) oraz Instytutu Prahistorii UAM w Poznaniu. Ilość 
grodzisk rozpoznanych dendrochronologicznie do roku 2000 (ponad 40 obiektów, w tym warownie tej klasy co Poznan, Gniezno, Giecz, Ostrów Lednicki; liczba znaczna $w$ porównaniu $z$ innymi częściami Polski, gdzie realizowane są analogiczne przedsięwzięcia badawcże), lokalizacja wspomnianych stanowisk w różnych częściach regionu, wreszcie ich chronologia, uwzględniająca zarówno starsze, jak i młodsze fazy wczesnego średniowiecza (IX-XIII wiek), pozwoliły sformułować pierwsze uogólnienia dotyczące wyników programu oraz metod pobierania prób drewna'. Szczególną uwagę zwrócono na przydatność bezwzględnych wskazań dendrochronologii w studiach nad periodyzacją wczesnego średniowiecza w Wielkopolsce oraz w analizie sytuacji osadniczej tegoż regionu w różnych fazach podokresu, jednak pod warunkiem respektowania określonych reguł metodycznych. Niedopuszczalne jest operowanie próbami pozbawionymi funkcjonalno-przestrzennego kontekstu, jak też wyciaganie jednoznacznych wniosków na podstawie pojedynczych bądź nielicznych oznaczeń. Korzystanie $z$ ekspertyz dendrochronologicznych nie zwalnia archeologa $\mathrm{z}$ obowiązku konfrontacji dendrodat $\mathrm{z}$ rezultatami własnej, autonomicznej analizy metrykalnej stanowiska oraz sekwencji stratyfikacyjnych, z których pobrano próby drewna.

Wypada zaznaczyć, iż uzyskane wyniki wydatnie przyczyniły się do zdefiniowania dendrochronologicznego standardu dębu dla terenów Wielkopolski, który obejmuje okres od schyłku starożytności (AD 449) po współczesność. Ów regionalny standard - jedyny tego rodzaju w Polsce, sukcesywnie uzupełniany - pozwala skutecznie datować próby drewna, w tym zwęglone, zapewniając jednocześnie pełną wiarygodność oznaczeń ${ }^{2}$. Dla badaczy średniowiecza ma to istotne znaczenie, zważywszy poważne niedokładności $w$ ocenie wieku znalezisk $\mathrm{z}$ tego okresu, jakie ujawnia stosowana dotychczas metoda pomiaru ilości węgla radioaktywnego ${ }^{3}$.

Realizowanym programem objęto wczesnośredniowieczne grodziska rozpoznane archeologicznie, głównie podczas badań tzw. milenijnych, charakteryzujące się stosunkowo precyzyjną metryką ustaloną konwencjonalnie oraz dobrze zachowanymi elementami drewnianych konstrukcji umocnień, ewentualnie zabudowy majdanu czy prowadzących do grodu mostów lub grobli. $\mathrm{Z}$ czasem badania rozszerzono o znaleziska szkutnicze wydobyte $\mathrm{z}$ fosy $\left(\mathrm{Lacd}^{4}\right)$ lub $\mathrm{z}$ dna jeziora oblewającego pobudowany na wyspie gród (Ostrów Lednicki ${ }^{5}$ ).

Do rozpatrywanej grupy stanowisk zaliczono m.in. warownie nadobrzańskie (Bonikowo, Bruszczewo, Daleszyn) oraz bogato stratyfikowane grodziska z central-

${ }^{1}$ Krapiec 1998a, s. 257-266; 1998b, s. 59 n.; Kurnatowska 1998, s. 31-36; Kara 2000c, s. 55-68; Kara, Krapiec 2000, s. 303 n.

${ }^{2}$ Standard sporządził dr hab. M. Krapiec z Akademii Górniczo-Hutniczej w Krakowie (por. Krąpiec 1998b).

${ }^{3} \mathrm{Na}$ ten temat np. Eosiński 1990, s. 39, 40.

${ }^{4}$ Krapiec 1998b, s. 72; Ossowski, Krapiec 1999, s. 158-163.

${ }^{5}$ Górecki 1998, s. 401; Ossowski 1999, s. 186. 
nych i północnych rejonów Wielkopolski (Gniezno-Góra Lecha, Kłecko, Kruszwica, Poznań-Ostrów Tumski, Santok), których chronologiczna analiza w walnym zakresie przyczyniła się do wyróżnienia w obrębie wczesnośredniowiecznej kultury dorzecza Warty sześciu faz obejmujących lata około $400 / 500-1350^{6}$. Z wymienionych obiektów pozyskano bowiem zróżnicowane składem oraz charakterem zespoły mobilnych znalezisk, złożone z ceramiki naczyniowej oraz zabytków tzw. wydzielonych, w tym luksusowych przedmiotów interregionalnych, spełniających kryteria niezależnych wyznaczników chronologii wczesnego średniowiecza (np. uzbrojenie; ozdoby - głównie paciorki; grzebienie; monety). W przypadku analizowanych stanowisk wspomniane zespoły zalegały w kolejnych poziomach osadniczych majdanu, powiązanych stratygraficznie bądź chronologicznie z reliktami drewniano-ziemnych umocnień.

Nie jest kwestią przypadku, iż wśród pierwszych analizowanych grodzisk, zatem szczególnie istotnych dla weryfikacji wielkopolskich faz wczesnego średniowiecza, znalazła się warownia w Bninie (ob. Kórnik-Bnin), woj. wielkopolskie, wyróżniona jako stanowisko 2a, sprzężona z osadą przygrodową, oznaczoną jako stanowisko $2 \mathrm{~b}$ (ryc. 1). Ów obronny zespół - z czasem uzupełniony o tzw. fermetę (stanowisko 1), blokująca dostęp do grodu - pobudowano w południowej oraz centralnej części rozległego półwyspu „Szyja” Jeziora Bnińskiego, oddalonego około $25 \mathrm{~km}$ na południowy wschód od Ostrowa Tumskiego w Poznaniu. Człony bnińskiego zespołu osadniczego zostały zbadane w latach 1961-1969 przez ekspedycję archeologiczną działającą pod kierunkiem Jana Żaka - początkowo w strukturach Zakładu Archeologii Wielkopolski i Pomorza Instytutu Historii Kultury Materialnej PAN w Poznaniu, a od roku 1964 w ramach Katedry Archeologii Polski i Powszechnej Uniwersytetu Poznańskiego.

Mimo nierównomiernego stanu rozpoznania poszczególnych założeń, dodajmy - zazwyczaj eksplorowanych wąskoprzestrzennym wykopem sondażowym, grodowy zespół w Bninie jest jedynym z terenu Wielkopolski, dla którego dysponujemy niemal pełnym profilem stratyfikacyjnym zbadanego terenu, przecinającym zarejestrowane stanowiska wzdłuż przybliżonej osi północ - południe i obejmującym nawarstwienia od aktualnej powierzchni gruntu do stropu skały macierzystej (ryc. 1). Ze względu na wysoki stan wód podskórnych tylko majdan grodziska wklęsłego rozkopano w niewielkiej południowej partii przywałowej, rezygnując z przedłużenia wykopu w kierunku północnym i połączenia go z przeciwległym, zlokalizowanym u zewnętrznego podnóża północnej części obwarowania. Wyniki badań archeologicznych poszczególnych członów bnińskiego zespołu obronnego zostały opublikowane w oddzielnych monografiach źródłoznawczych, które przygotowano według wzorca ustalonego dla wykopalisk poznańskiego kompleksu grodowego?

${ }^{6}$ Por. Hensel 1950, s. 5, 6; Hilczerówna 1967, s. 50 n.; Dzieduszycki 1982; 1990, s. 155-159; Kurnatowska, Łosińska 1990, s. 105 n.

${ }^{7}$ Pałubicka 1975; Krause 1976; Szamałek, Dudziak-Jankowiakowa, Karolczak 1979. 
Zawarto w nich szczegółowy opis nawarstwień odsłoniętych w wykopach, wraz z katalogiem znalezisk mobilnych i nieruchomych, do których dołączono ryciny zabytków oraz reprezentatywny wybór czarno-białych fotografii, jak też skalowanych planów poziomych i profili, odwzorowujących konkretne sytuacje stratygraficzne, zdokumentowane podczas badań terenowych. Źródła przedstawiono w ujęciu stratygraficzno-chronologiczno-funkcjonalnym, czyli w kontekstualnych układach pionowych i poziomych, poddając je każdorazowo niezależnej analizie typologiczno-porównawczej oraz stratygraficzno-chorologicznej w ramach odkrytych zespołów. Przyjęty model publikacji, naszym zdaniem wysoce metodyczny (niestety, szerzej nie upowszechniony), jak również fakt sfinalizowania badań trzytomową monografią, syntetyzującym hasłem w Stowniku Starożytności Stowiańskich ${ }^{8}$ oraz studiami nad osadnictwem mikroregionu bnińskiego w pradziejach i średniowieczu", wyróżnia bniński zespół grodowy spośród innych rozpoznanych archeologicznie wielkopolskich osiedli obronnych wczesnego średniowiecza. Corpus ów umożliwia podjęcie wiarygodnych badań weryfikacyjnych (w tym terenowych), pozwala bowiem analizować znaleziska w ramach odkrytych układów stratyfikacyjnofunkcjonalnych poszczególnych członów zespołu, które uporządkowano we wzajemnie skorelowane poziomy osadnicze, wydatowane konwencjonalnie.

Uwaga ta dotyczy m.in. doskonale zachowanych reliktów drewnianego szkieletu wału grodziska wklęsłego, jak również fragmentu wyłożonej dylami drogi (ciągu komunikacyjnego) odsłoniętej na południowym skraju przygrodowej osady oraz kamienno-drewnianych lub drewnianych konstrukcji, jakie zalegają wokół podnóża tzw. gródka stożkowatego - fermety (najprawdopodobniej stabilizatory gruntu oraz odcinki nadbrzeżnych ciagów komunikacyjnych) ${ }^{10}$. Dodajmy, iż drewniane pozostałości umocnień bnińskiego grodu wklęsłego porównywalne są pod względem stanu zachowania z reliktami wczesnośredniowiecznych fortyfikacji na Górze Lecha w Gnieźnie oraz na Ostrowie Tumskim w Poznaniu, które zalicza się do spektakularnych odkryć polskiej archeologii ${ }^{11}$.

Nawarstwienia eksplorowano zgodnie z układem stratyfikacyjnym, a dokumentację sporządzono w sposób wysoce metodyczny (fotografie; kolorowe plany w skali $1: 10 \mathrm{z}$ naniesionymi opisami warstw oraz niwelacjami; inwentarze; dziennik prac polowych); również stan jej przechowywania oraz dostępność (Instytut Prahistorii UAM w Poznaniu) nie wzbudzają zastrzeżeń.

Istnieją zatem przesłanki, aby wydatowane dendrochronologicznie próby drewna $\mathrm{z}$ wymienionych konstrukcji bnińskich uznać za wiarygodne probierze metrykalnych ustaleń archeologii.

\footnotetext{
${ }^{8}$ Żak 1986, s. 488, 489.

${ }^{9}$ Żak, Fogel (red.) 1985.

II' Por. Pałubicka 1975, s. 26 n.; Krause 1976, s. 60 n., ryc. 8: 2, 3; Szamałek, Dudziak-Jankowiako-
} wa, Karolczak 1979, s. 85-89, ryc. 3: 2, 3.

" Por. Hensel 1962, ryc. 34-37. 
Według odkrywców ${ }^{12}$ interesujący nas zespół grodowy powstał w 2. połowie X w. Około roku 960 wzniesiono w centralnej części półwyspu pierścieniowaty gród - pierwotnie projektowany jako założenie dwuczłonowe, finalnie zrealizowany jako obiekt ufortyfikowany potężnym, drewniano-ziemnym wałem podkowiastym (o czytelnym do dzisiaj narysie), wysokości około 7-10 m, spiętrzonym w konstrukcji rusztowej wzmocnionej u podwalin wiązaniem hakowym, z owalnym majdanem o wymiarach około $60 \times 35 \mathrm{~m}$. Warownię pobudowano częściowo na skale macierzystej, a częściowo na aluwialnych sedymentach Jeziora Bnińskiego, przykrywajacych pozostałości osiedla ludności kultury łużyckiej z przełomu epoki brązu i wczesnej epoki żelaza. Południową część półwyspu zajmowała otwarta osada, założona podobnie jak gród - na przykrytych aluwiami reliktach osiedla pradziejowego. Zdaniem odkrywców najstarszą w tym miejscu wczesnośredniowieczną zabudowę należy łączyć bądź z początkiem X w. ${ }^{13}$, bądź ze schyłkiem 1. połowy tegoż stulecia ${ }^{14}$. $\mathrm{W} 2$. połowie $\mathrm{X} \mathrm{w}$. osadę przekształcono $\mathrm{w}$ sprzężone $\mathrm{z}$ warownią osiedle przygrodowe, oblane $\mathrm{z}$ trzech stron wodami jeziora, a od północy chronione potężnymi fortyfikacjami grodu. Według A. Pałubickiej i J. Żaka kres funkcjonowania zespołu nastapił w latach 30 . XI w., prawdopodobnie podczas wypadków związanych z kryzysem monarchii piastowskiej oraz najazdem czeskiego księcia Brzetysława I w roku 1038 lub 1039.

Odbudowę warowni wraz $\mathrm{z}$ otwartą osadą przygrodową badacze skłonni są umieszczać dopiero w końcu wieku XII (około roku 1200). Zespół reaktywowano w poprzedniej formie. Dokonano jednak rozbudowy podkowiastego wału grodu (w konstrukcji rusztowo-hakowej), a jego majdan poszerzono do około $75 \times 52 \mathrm{~m}$. Koniec założenia datowany jest na początek XIII stulecia (najprawdopodobniej rok 1233 według źródeł pisanych).

Zdaniem odkrywców trzecia, zarazem ostateczna renowacja grodu wraz z przyległą osadą otwartą nastąpiła jeszcze w roku 1233. Obronny wał wzmocniono potężną odsadzką zewnętrzną, która w południowej części fortyfikacji miała formę drewnianych skrzyń ujętych od frontu wiązaniem hakowym, wypełnionych kamieniami polnymi i przykrytych drewnianym stosem, spiętrzonym w konstrukcji rusztowej, uszczelnionej piaskiem. Nie zaobserwowano zmian w wymiarach oraz formie grodu. Na północnym przedpolu warowni wzniesiono w 2. ćwierci XIII w. tzw. fermetę, czyli odrębną strażnicę w formie stożkowatego „kopca” drewniano-ziemnego, z co najmniej jedną budowlą palisadową w partii przyszczytowej. Definitywny koniec bnińskiego kompleksu obronnego badacze łączą z początkiem 2. połowy XIII stulecia. Przyczyny wyludnienia półwyspu upatruje się w procesach społecznopolitycznych, jakie zachodziły w XIII-wiecznej Wielkopolsce, bądź w przypadającej 1993.

${ }^{12}$ Por. przypisy 7 i 8. Zob. też Kurnatowska, Losińska 1990, s. 143, nr 28, 28a, s. 146, nr 40; Fogel

${ }^{13}$ Szamałek, Dudziak-Jankowiakowa, Karolczak 1979, s. 252.

${ }^{14}$ Żak 1986, s. 488. 
na ten czas zmianie klimatu Niżu Europejskiego, która spowodowała poważne przybory wód rzek i jezior, dodatkowo spotęgowane intensywnym wyrębem lasów pod licznie zakładane osiedla ${ }^{15}$.

Forma najstarszego grodu bnińskiego, jego wymiary oraz technika budowy wału (konstrukcja rusztowa $\mathrm{z}$ wiązaniem hakowym), nadto materiały ruchome znalezione w nawarstwieniach majdanu i osady podgrodowej, pozwoliły postawić hipotezę, iż mamy do czynienia $z$ inwestycją sięgającą czasów piastowskich. Według A. Pałubickiej i J. Żaka warownię pobudowano z inicjatywy Mieszka I jako ośrodek zarządu terytorialnego niższego szczebla, jednocześnie ważny punkt oporu, blokujący w obronnym $\mathrm{z}$ natury miejscu dostęp do grodu poznańskiego, z racji położenia na strategicznym szlaku, który poprzez śremskie brody na Warcie łączył jądro monarchii piastowskiej ze Śląskiem ${ }^{16}$. Z kolei pobudowane na półwyspie „Szyja” warownie z 1. połowy XIII - początku 2. połowy XIII w. uznaje się za silnie ufortyfikowane centra bnińskiej kasztelanii militarnej lub nieterytorialnej, zlikwidowanej w 2. połowie XIII stulecia ${ }^{17}$.

Do badań dendrochronologicznych wytypowano zewnętrzne, skrajne odcinki drewniano-ziemnego wału grodziska wklęsłego (stan. 2a), odkryte przez ekspedycję J. Żaka w latach 1967-1968 na arze 268A-B, w wykopie tzw. północnym, którym wcięto się około 3-4 m w głąb zewnętrznego skłonu zachowanego nasypu północnego wału grodu (ryc. 1 i 2 ). Za takim wyborem przemawiały względy natury technicznej, przede wszystkim stosunkowo niewielka głębokość zalegania konstrukcji, sugerująca sprawny przebieg prac terenowych, jak również doskonały stan zachowania drewna dębowego, poświadczony dokumentacją oraz informacjami J. Fogla, zastępcy kierownika ekspedycji bnińskiej, nadto dwufazowość reliktów ${ }^{18}$ oraz fakt, iż według opinii odkrywców wyznaczały one zewnętrzny skłon obwarowań łączonych z grodami wzmiankowanymi w XIII-wiecznych źródłach pisanych ${ }^{19}$.

Badania weryfikacyjno-sondażowe przeprowadzono w dniach od 12 do 25 października 1994 r., za zgodą konserwatora zabytków archeologicznych na woj. poznańskie $^{20}$. Założono trzy wykopy sondażowe; próby dendrochronologiczne pozyska-

${ }^{15}$ Pałubicka 1975, s. 179, 180; Krause 1976, s. 108; Żak 1986, s. 489.

${ }^{16}$ Pałubicka 1975, s. 173 n.; Żak 1986, s. 488.

${ }^{17}$ Pałubicka 1975, s. 167 n.; Żak 1986, s. 489. Zob. też Leśny 1976, s. 5 n. (tam dalsza literatura).

${ }^{18}$ Pałubicka 1975, s. 142-154, tabl. LIV.

${ }^{19}$ Pałubicka 1975, s. 142 n.; Żak 1986, s. 488, 489, ryc. 306.

${ }^{20}$ Uczestniczyli w nich autorzy niniejszego tekstu; okresową współpracą służyli archeologowie mgr T. Krysztofiak oraz mgr B. Kościński. Wykopaliska konsultowali prof. Z. Kurnatowska i mgr A. Łosińska z Instytutu Archeologii i Etnologii PAN - Oddział w Poznaniu (dalej IAE PAN - Poznań) oraz prof. J. Fogel z Instytutu Prahistorii Uniwersytetu Poznańskiego. Dokumentacja w archiwum Pracowni Wczesnośredniowiecznej IAE PAN - Poznań. Szczególowy opis znalezisk wraz z dokumentacją graficzną wykopów zamieszczono w przygotowywanym do druku korpusie źródeł z badań dendrochronologicznych wczesnośredniowiecznych grodzisk Wielkopolski, które przeprowadzono w latach 19902000 . 
$71,5 \mathrm{~m}$ n.p.m.

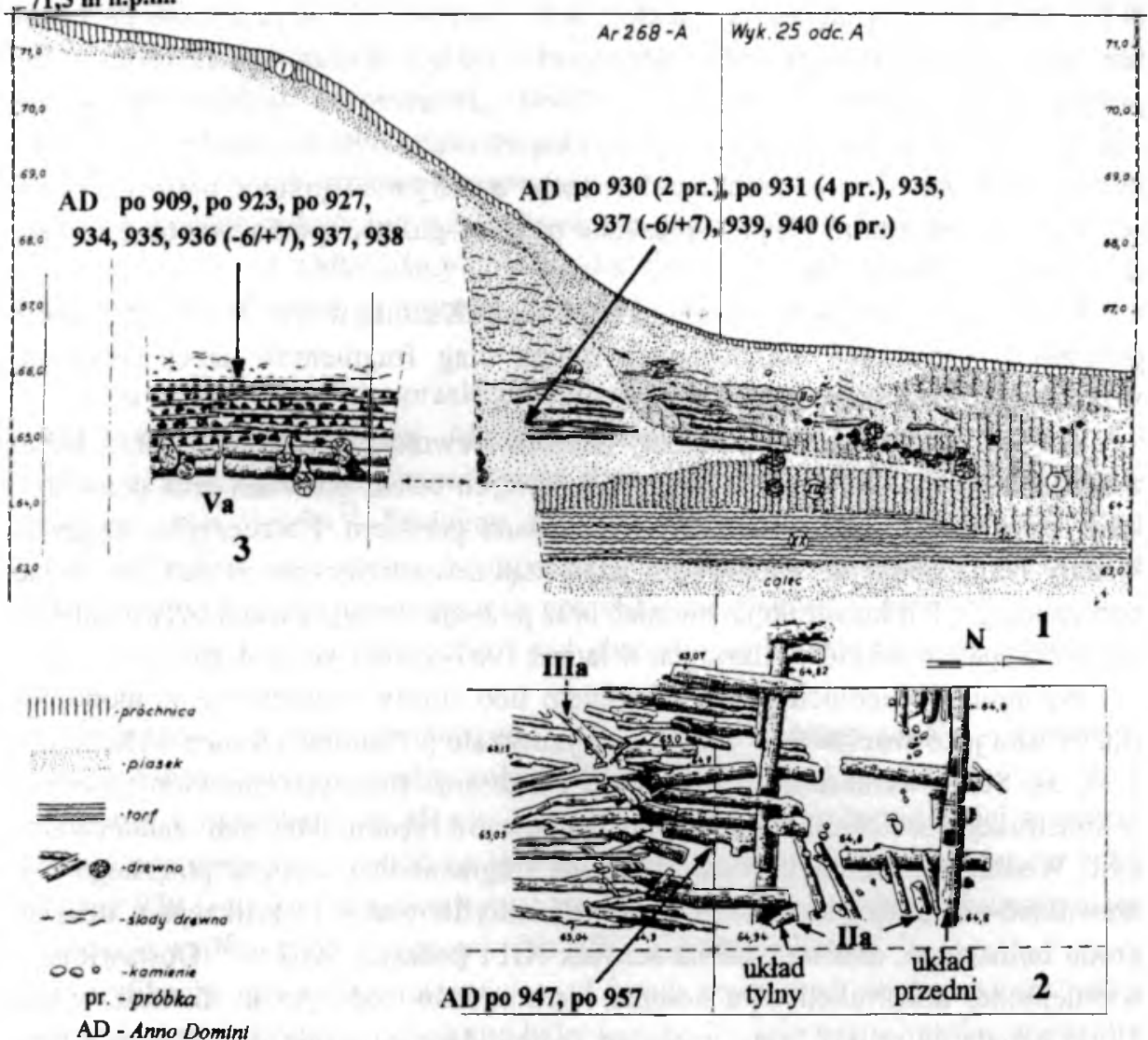

Ryc. 2. Bnin, gm. Kómik, woj. wielkopolskie, stan. 2a. Profile zachodniej i południowej ściany wykopu tzw. północnego oraz rzut poziomy reliktów drewnianych konstrukcji wału grodu ( $\mathrm{nr}$ Va, IIIa, IIa), odkrytych w wykopie, wraz z dendrodatami prób pobranych z wymienionych konstrukcji w sondażach nr I-II/1994 (oprac. M. Kara na podstawie A. Pałubickiej 1975, tabl. LIV)

Abb. 2. Bnin, Gem. Kórnik, Woi. Wielkopolska (Großpolen), Fst. 2a. Profile der westlichen und südlichen Wand der sogenannten nordlichen Grabungsfläche und GrundriB der Relikte von Holzkonstruktionen des Burgwalls (Nr. Va. IIIa, Iia), die in der Grabungsfläche freigelegt wurden, mit Dendrodaten der Proben, die aus den genannten Konstruktionen in den Sondierungen Nr. I-II/1994 entnommen wurden (erarbeitet von M. Kara auf Grund von A. Palubicka I975, Taf. LIV)

no z dwu oznaczonych numerami I-II/1994 (ryc. 3). Pierwszy - o wymiarach 4,4 (oś E-W) $\times 1,5 \mathrm{~m}$ (oś N-S) i maksymalnej głębokości około 3,2 m - zlokalizowano w południowej partii wykopu J. Żaka, przy czym zachodni skraj sondażu stanowił poszerzenie wymienionego wykopu. Drugi - o wymiarach I,3 (oś E-W) $\times 2 \mathrm{~m}$ (oś 
$\mathrm{N}-\mathrm{S}$ ) i maksymalnej głębokości około 1,4 m - wytyczono na przedpolu grodziska, tuż przy krawędzi nasypu wału, naprzeciwko zakrętu obwarowania, 6,5 m w linii prostej od SW narożnika sondażu nr I/1994. „Poszerzenie” wykopu badawczego z lat 1967-1968 o partie dotychczas nie eksplorowane było niezbędne, zważywszy, iż odsłonięte wówczas konstrukcje drewniane zostały niewątpliwie narażone (mimo powtórnego zasypania) na przyśpieszone procesy gnilne, spowodowane zwiększonym dostępem powietrza.

W tej sytuacji próby dendrochronologiczne ( 28 sztuk, w tym 25 wydatowanych) pobrano $\mathrm{z}$ konstrukcji stanowiących dalszy ciag fragmentów zarejestrowanych w latach 60. przez ekspedycję J. Żaka.

W roku 1994 odkryto zewnętrzny odcinek drewnianego szkieletu wału, złożony $\mathrm{z}$ trzech rzędów stosów spiętrzonych z dębowych belek, bierwion oraz półokrąglaków, które w celach stabilizacyjnych obsypano piaskiem. Poszczególne rzędy nakładały się na siebie pierścieniowato, czyli rząd zewnętrzny opierał się o lico układu poprzedniego. Ich konstrukcja, budulec oraz pozycja stratygraficzna były identyczne jak w przypadku reliktów odkrytych w latach 1967-1968 (ryc. 2; 4-6).

Wzorem poprzednich badań odsłonięto lico stosów wyróżnione w monografii stanowiska jako warstwa $\mathbf{n r}$ Va, które wyznaczało południową ścianę wykopu (ryc. $2,4,5)$. Stosy wzniesiono $\mathrm{z}$ dębowych belek oraz łupanych bierwion ułożonych w konstrukcji rusztowej, wzmocnionej u podwalin rzędem hakowato zakończonych dyli. Według A. Pałubickiej natrafiono na fragment lica korpusu potężnego wału drewniano-ziemnego, który skłonna była identyfikować z fortyfikacjami drugiego grodu bnińskiego, datowanymi na schyłek XII i początek XIII w. ${ }^{21}$ Dostawione do wymienionej konstrukcji dwa kolejne rzędy stosów (odkryto je również w roku 1994) uznała za relikty wału trzeciego (najmłodszego) grodu bnińskiego, którego istnienie w 2. ćwierci wieku XIII oraz na początku 3. ćwierci tegoż stulecia ustaliła na podstawie analizy materiałów archeologicznych oraz informacji XIII-wiecznych źródeł pisanych ${ }^{22}$. Uszczelniony piaskiem „wewnętrzny” rząd stosów - oznaczony jako warstwa nr IIIa - spiętrzono z łupanych bierwion dębowych ułożonych w konstrukcji rusztowej. W 1994 r. odkryto je w sondażu nr I, gdzie przylegały do lica stosów nr Va (ryc. 2, 4, 5). Charakter reliktów nie pozostawia wątpliwości, iż w przypadku warstwy nr IIIa mamy do czynienia $z$ frontem odnowionego wału obronnego. Drugi z interesujących nas układów - wyróżniony jako tylna konstruk-

${ }^{21}$ Pałubicka 1975, s. 142, 143, 156-159, 163-165, tabl. LIV, LXI.

${ }^{22}$ Pałubicka 1975 , s. 143-154, 156-159, 165-167, tabl. LIV, LVII, LIX, LXI. Wypada zaznaczyć, iž odsłonięte $w$ wykopie tzw. północnym relikty konstrukcji wałowych pozostawały bez relacji stratygraficznych $\mathrm{z}$ warstwami majdanu (por. ryc. 1 i 2). Zostały wydatowane na podstawie przestrzennej korelacji z pozostałościami wału zarejestrowanymi w przeciwległym wykopie, tzw. południowym, w którym zbadano również przywałową partię wnętrza grodziska (Pałubicka 1975, s. 156-159). Z punktu widzenia postępowania badawczego zastosowana metoda jest bardzo ryzykowna. 
cja $\mathrm{z}$ warstwy IIa - A. Pałubicka zinterpretowała jako fundament zniwelowanego podczas drugiej wojny światowej korpusu wału, z potężną drewniano-ziemną odsadzką zewnętrzną (jej pozostałości wyróżniła jako przedni układ warstwy nr IIa). Próby dendrochronologiczne pobrano jedynie ze spagu tylnej konstrukcji $\mathrm{nr}$ IIa, którą w 1994 r. zarejestrowano fragmentarycznie w sondażu nr II (bez lica wzmocnionego hakowato zakończonymi belkami, co poświadczyły badania naszych poprzedników - ryc. 2). Odkryliśmy tylko pokład dębowych półokraglaków, ułożonych ciasno jeden przy drugim, zetkniętych od poludnia z bierwionami konstrukcji nr IIIa (ryc. 6).

Pozyskane próby drewna przekazano do analizy drowi hab. M. Krapcowi z Pracowni Dendrochronologicznej Akademii Górniczo-Hutniczej w Krakowie. Ku naszemu zaskoczeniu, otrzymane wyniki ujawniły obraz odmienny od zarysowanego przez archeologów ${ }^{23}$. Dodajmy, iż datowanie bnińskiego zespołu osadniczego nie wzbudzało dotychczas kontrowersji, a ustalenia metrykalne poczynione dla materiałów ruchomych (zwłaszcza ceramiki naczyniowej) stanowiły niejednokrotnie punkt odniesienia w studiach nad chronologią innych grodzisk wielkopolskich.

Stwierdzono, iż stosy wewnętrzne - zaliczone do warstwy nr Va - spiętrzono z drewna dębów ściętych między rokiem 934 a 938, natomiast stosy zewnętrzne rozpoznane w warstwie nr IIIa - skonstruowano najprawdopodobniej $z$ dębów zwalonych $w$ roku 940, sporadycznie wykorzystując budulec zgromadzony w roku 935 oraz 939 (ryc. 2). Przypomnijmy - według ustaleń A. Pałubickiej wymienione konstrukcje wałowe pochodzą ze schyłku XII - 1. połowy XIII w.

Fortyfikację odnowiono dostawiając od frontu nowy rząd stosów w konstrukcji rusztowej, spiętej u podwalin belkami hakowatymi. Te sekwencje stosów wyróżniono jako warstwę nr IIa; być może wyznaczały one zewnętrzną odsadzkę wału (ryc. 2). Określono metrykę ścięcia dwu dębów, z których wykonano półokrąglaki moszczące spag konstrukcji: po 947 oraz po 957 r. Stosy nr IIa A. Palubicka wydatowała na wiek XIII.

$\mathrm{Z}$ rozkładu dendrodat wynika, iż odsłoniętą partię bnińskiego wału wznoszono w dwu etapach, z przerwą w roku 939. Etap starszy sfinalizowano w 938; najprawdopodobniej został on rozpoczęty około roku 934 , ewentualnie w tym czasie podjęto gromadzenie budulca, natomiast młodszy ukończono w AD 940, wykorzystując m.in. bierwiona $z$ dębów ściętych w roku poprzednim.

Lokalizacja prób, ograniczona wyłącznie do zewnętrznego odcinka wału, nie pozwala rozstrzygnąć, czy rok 934 wyznacza początek budowy grodu, czy tylko zaawansowaną renowację istniejącego już założenia. Odnotujmy jednak dwie den-

\footnotetext{
${ }^{23}$ Krapiec 1998a, s. 262, 263; 1998b, s. 77 n., ryc. 59 (tu popełniono błąd, wyniki B dotyczą bowiem warstwy nr Va, natomiast wyniki A odnoszą się do warstwy nr IIIa).
} 
drodaty - po roku 925 oraz październik 928 - maj 929 (czas ścięcia) - uzyskane dla prób pochodzących być może z jednej belki dębowej, którą na pewno odkryto w Bninie w latach 60. podczas badań wykopaliskowych grodziska wklęsłego, najprawdopodobniej $w$ przekopie przez południową partię wału (próby dostarczył J. Fogel). Według M. Krapca ${ }^{24}$ dąb zwalono najpóźniej około roku 930, zatem belka może pochodzić z konstrukcji wałowej nieco starszej niż relikty odkryte w wykopie tzw. północnym.

Pokaźna ilość prób oraz zwarty charakter oznaczeń wykluczają błąd dendrochronologii. Wcześniejszą metrykę konstrukcji nr IIIa oraz IIa zdają się potwierdzać materiały ceramiczne pozyskane $\mathrm{z}$ wymienionych sekwencji stratygraficznych (stosy nr Va nie ujawniły zabytków) ${ }^{25}$. W obu przypadkach mamy do czynienia z fragmentami naczyń kultury łużyckiej (ewidentnie na złożu wtórnym) oraz ułamkami wczesnośredniowiecznych pojemników charakterystycznych dla południowej Wielkopolski X - 1. połowy XI w. ${ }^{26}$ Ilość wczesnośredniowiecznej ceramiki znalezionej w tzw. tylnym układzie sekwencji nr IIa (182 fragmenty - zdecydowana dominacja pojemników obtaczanych góra, głównie typu Tornow według J. Herrmanna ${ }^{27}$, nad okazami obtaczanymi całkowicie), nadto znaczne rozdrobnienie materiału, sugeruja wtórną depozycję artefaktów, które do wnętrza konstrukcji mogły w zdecydowanej większości trafić wraz ziemią czerpaną z osady nieco starszej niż wznoszona fortyfikacja, bowiem forma naczyń oraz struktura technotypów są charakterystyczne dla zespołów ceramicznych $\mathrm{z} 1$. połowy (2. ćwierci?) $\mathrm{X}$ - początku 2. połowy $\mathrm{X}$ w. Podobne znamy m.in. z najstarszych stratygraficznie reliktów bnińskiej osady przygrodowej $^{28}$. Przypomnijmy, że według wskazań dendrochronologii wałową konstrukcję nr IIa wzniesiono z drewna ściętego po roku 957.

Uzyskane dendrodaty wpisują bnińską warownię w horyzont wielkopolskich grodów pobudowanych w latach około 935-940/945, co wykazały analizy dendrochronologiczne drewnianych konstrukcji wałów. W tym czasie wzniesiono m.in. warownie na Górze Lecha w Gnieźnie, w Grzybowie-Rabieżycach, Gieczu oraz Lądzie, przy czym w trzech ostatnich przypadkach dokonano gruntownych renowacji starszych założeñ ${ }^{29}$. Wymienione grodziska (z wyjątkiem Lądu) leżą w pobliżu Bnina.

Nie ulega zatem wątpliwości, iż środowisko poznańskich archeologówmediewistów stanęło przed koniecznością podjęcia badań weryfikujących chronologię bnińskiego zespołu osadniczego.

\footnotetext{
${ }^{24}$ Informacja ustna $\mathrm{z}$ dnia $25.04 .200 \mathrm{I} \mathrm{r}$.

${ }^{25}$ Pałubicka 1975, s. 142-I54, tabl. LVI, LVIII.

${ }^{26}$ Por. Hilczerówna 1967; Hilczer-Kurnatowska, Kara 1994; Kara 2000b.

${ }^{27}$ Herrmann 1966.

${ }^{28}$ Kara 2000b, s. 489 n. (tam dalsza literatura).

${ }^{29}$ Kara 2000a, Abb. 1; 2000b, s. 493 n. (w obu pracach dalsza literatura).
} 


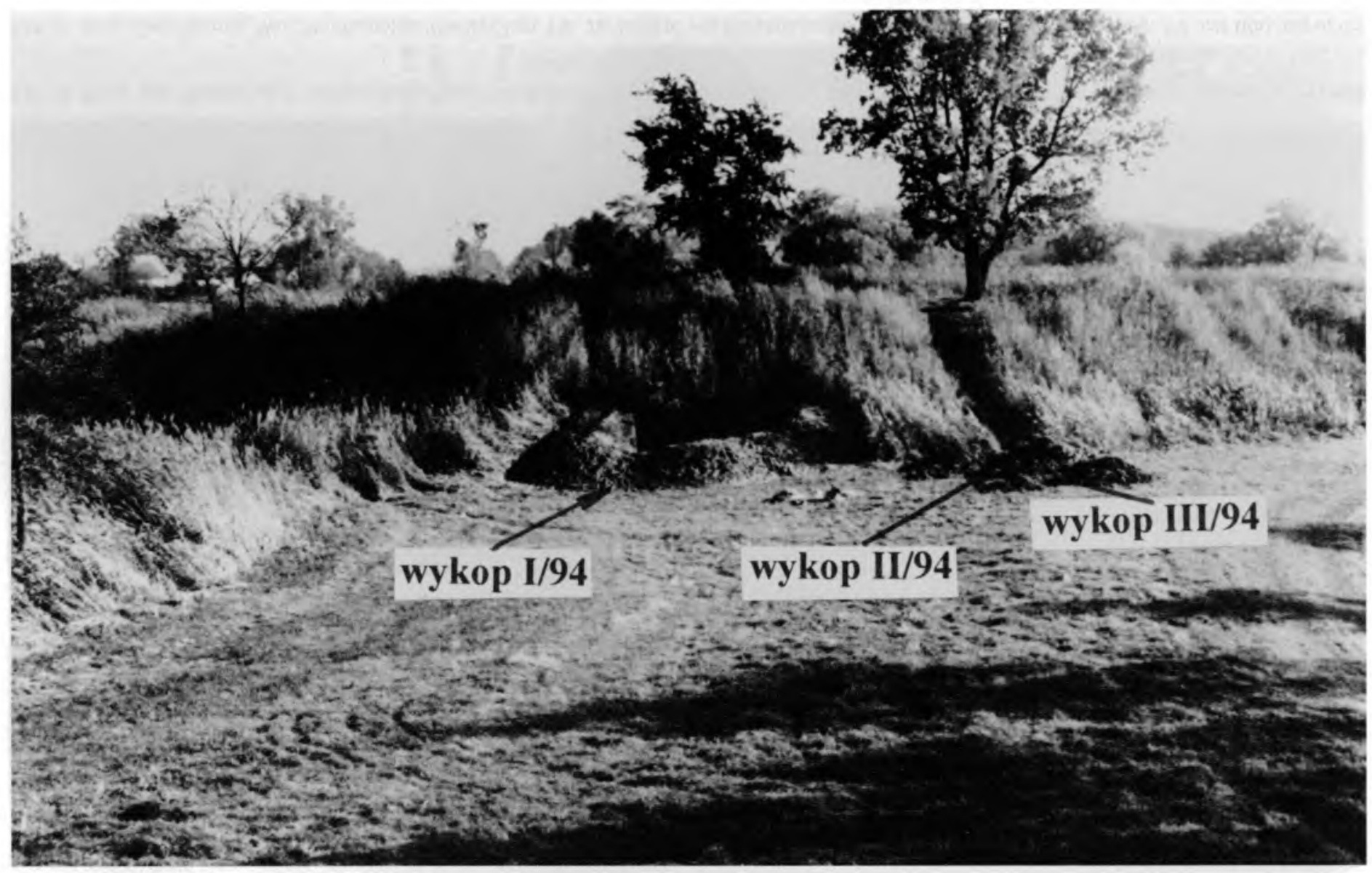

Ryc. 3. Bnin, gm. Kórnik, woj. wielkopolskie, stan. 2a. Lokalizacja wykopów sondażowych nr I-III/1994, założonych u zewnętrznego podnóża północnego odcinka wału grodziska (fot. M. Kara)

Abb. 3. Bnin, Gem. Kórnik, Woi. Wielkopolska (Großpolen), Fst. 2a. Lage der Grabungsflächen der Sondierungen Nr. I-III/1994, die am äußeren Fußgestell des nördlichen Burgwallabschnitts eingerichtet wurden (Photo M. Kara) 


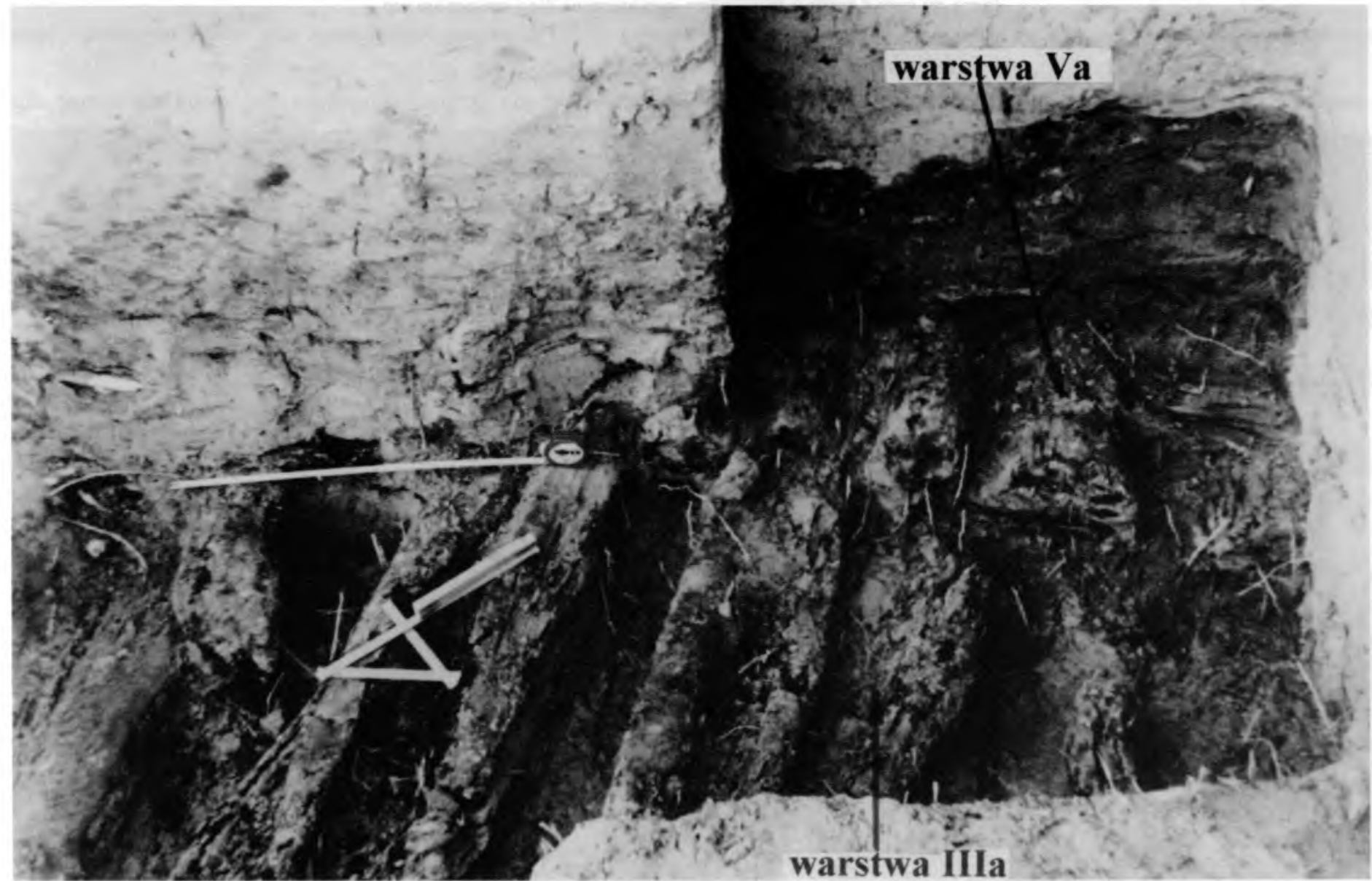

Ryc. 4. Bnin, gm. Kórnik, woj. wielkopolskie, stan. 2a. Relikty drewnianych konstrukcji wału grodu (warstwy nr Va oraz IIla), odkryte w wykopie sondażowym nr I/1994 (fot. M. Kara)

Abb. 4. Bnin, Gem. Kórnik, Woi. Wielkopolska (Großpolen), Fst. 2a. Relikte von Holzkonstruktionen des Burgwalls (Schichten Nr. Va und IIIa), die in der Grabungsfläche der Sondierung Nr. I/1994 freigelegt wurden (Photo M. Kara) 


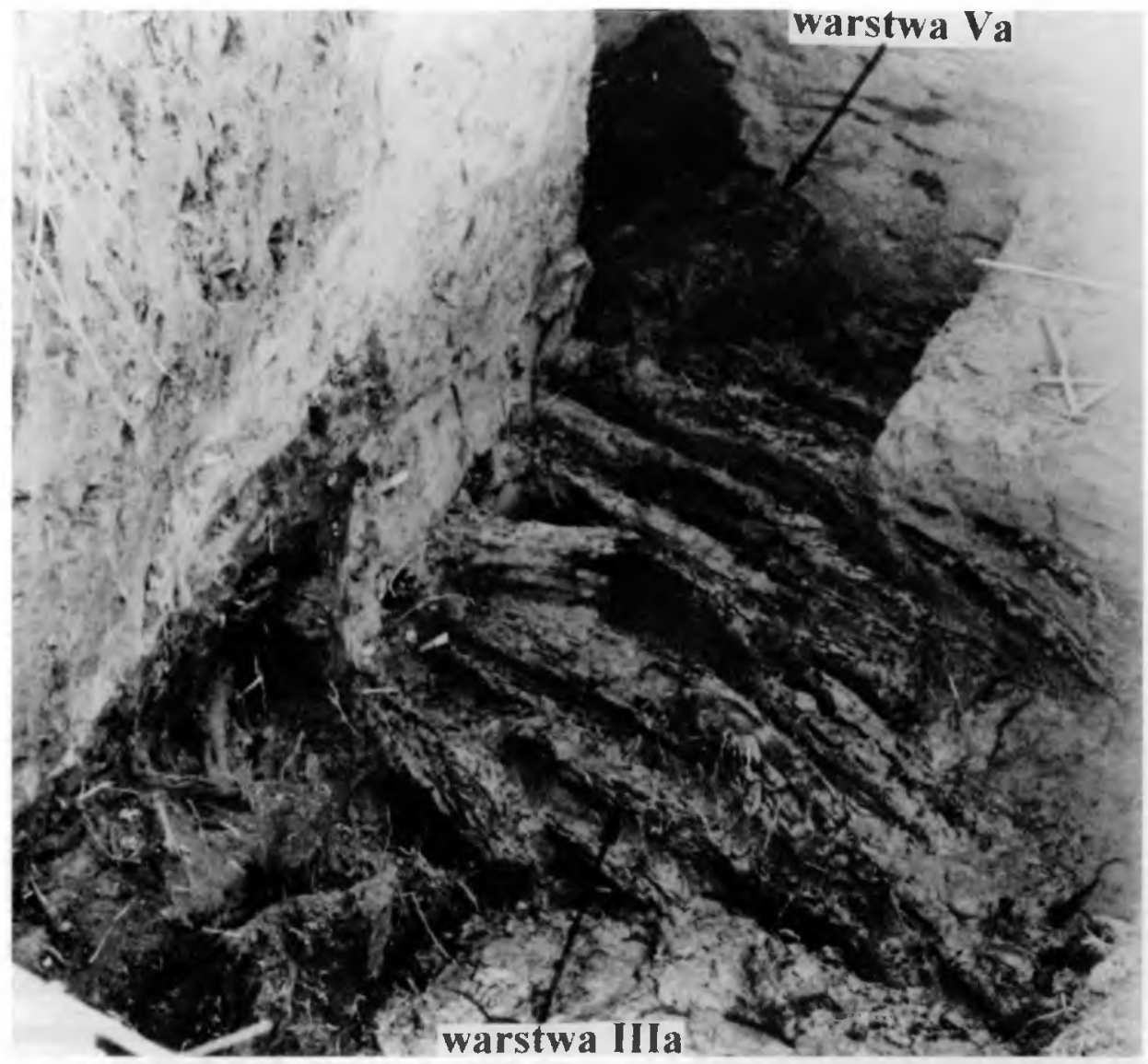

Ryc. 5. Bnin, gm. Kórnik, woj. wielkopolskie, stan. 2a. Relikty drewnianych konstrukcji wału grodu (warstwy nr Va oraz IIIa), odkryte w wykopie sondażowym nr I/I994 (fot. M. Kara)

Abb. 5. Bnin, Gem. Kórnik, Woi. Wielkopolska (Großpolen), Fst. 2a. Relikte von Holzkonstruktionen des Burgwalls (Schichten Nr. Va und IIIa), die in der Grabungsfläche der Sondierung Nr. I/1994 freigelegt wurden (Photo M. Kara) 


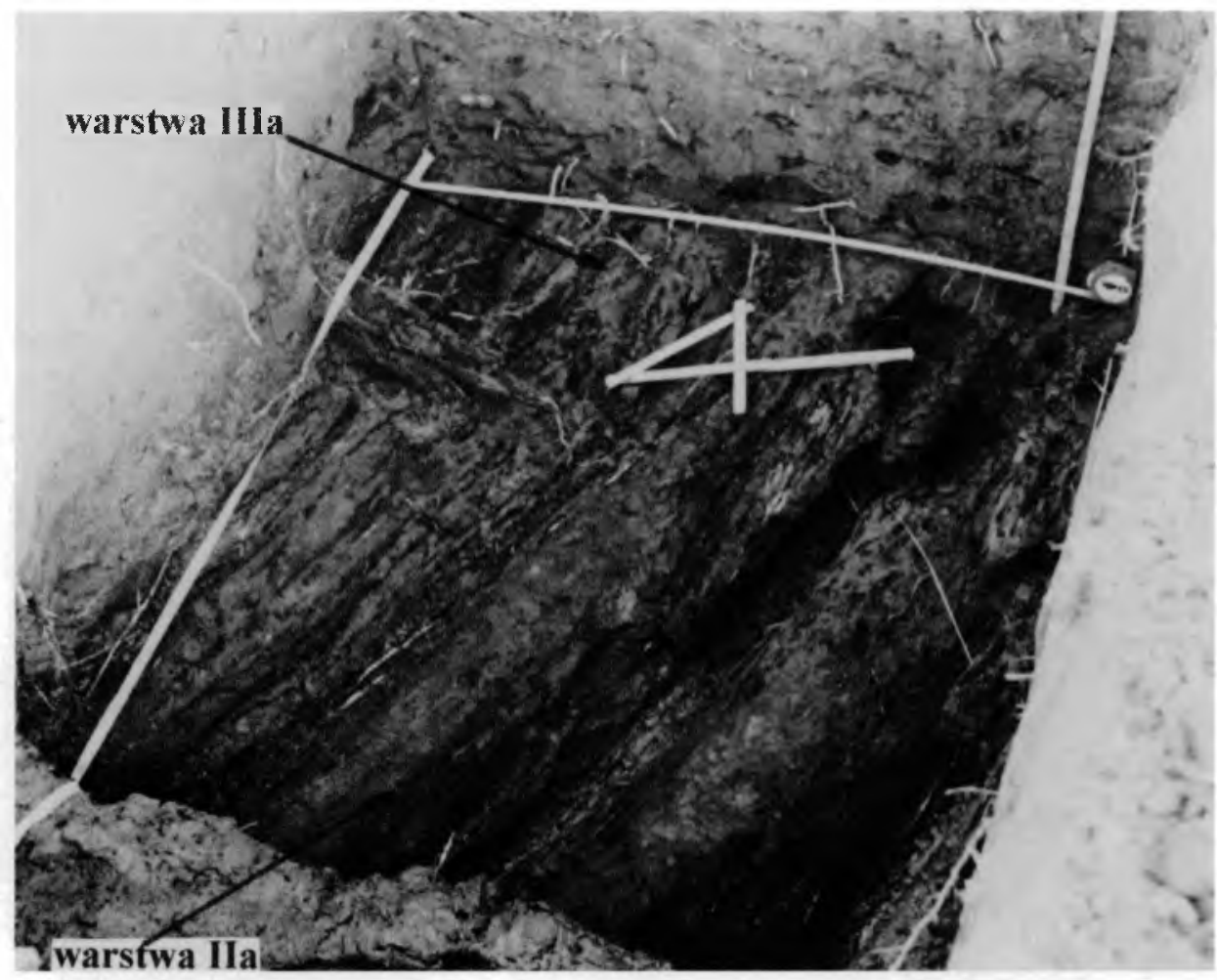

Ryc. 6. Bnin, gm. Kórnik, woj. wielkopolskie, stan. 2a. Relikty drewnianych konstrukcji wału grodu (warstwy nr IIIa oraz IIa - tzw. układ tylny), odkryte w wykopie sondażowym nr II/1994 (fot. M. Kara)

Abb. 6. Bnin, Gem. Kórnik, Woi. Wielkopolska (Großpolen), Fst. 2a. Relikte von Holzkonstruktionen des Burgwalls (Schichten Nr. IIIa und IIa - sogenannte hintere Anordnung), die in der Grabungsfläche der Sondierung Nr. IL/1994 freigelegt wurden (Photo M. Kara) 


\section{BIBLIOGRAFIA}

Dzieduszycki W.

1982 Wczesnomiejska ceramika kruszwicka w okresie od 2 potowy $X$ w. do potowy XIV w. [Sum. The early-urban Kruszwica ceramics from the second half of the $10^{\text {th }}$ to the mid- $14^{\text {th }}$ centuries], Wrocław - Warszawa - Kraków - Gdańsk - Łódź.

1990 Podstawy periodyzacji okresu wczesnośredniowiecznego w Wielkopolsce, (w:) Stan i potrzeby badań nad wczesnym średniowieczem $w$ Polsce (red. Z. Kurnatowska), Poznań Wroclaw - Warszawa 1992, s. 155-159.

Fog e I J.

1993 Mit i rzeczywistość „grodu” ludności kultury lużyckiej w Bninie, w środkowej Wielkopolsce (nie odosobniony przyktad funkcjonowania pótprawd we wspótczesnej archeologii polskiej) [Zus. Die Mythe und die Wirklichkeit der „Burg” der Bevölkerung der Lausitzer Kultur in Bnin, im mittleren Grosspolen], Poznań.

Górecki J.

1998 Lednicka tódź-powrót do źródet, „Studia Lednickie”, t. V, s. 401-403.

Hensel W.

1950 Studia i materialy do osadnictwa Wielkopolski wczesnohistorycznej, t. I, Poznań.

1962 Budownictwo obronne za czasów pierwszych Piastów [Rés. La construction défensive aux temps des premiers Piasts], (w:) Poczqtki państwa polskiego. Księga tysiqclecia, t. I (red. K. Tymieniecki), Poznań, s. 163-186.

Herrmann $J$.

1966 Tornow und Vorberg. Ein Beitrag zur Frühgeschichte der Lausitz, Berlin.

\section{Hilczerówna Z.}

1967 Dorzecze gómej $i$ środkowej Obry od VI do początów XI wieku [Sum. The basin of the Upper and Middle Obra from the VIth to the beginnings of the XIth century], Wrocław Warszawa-Kraków.

H i lczer-Kurnatowska Z., Kara M.

1994 Die Keranik vom 9. bis zur Mitte des 11. Jahrhunderts in Großpolen, (w:) Slawische Keramik in Mitteleuropa vom 8. bis zum 11. Jahrhundert (red. Č. Stan̆a), Brno, s. 121-141.

$\mathrm{K}$ a г a $\mathrm{M}$.

2000a Anfänge der Bildung des Piastenstaates im Lichte neuer archäologischer Ermittlungen, "Quaestiones Medii Aevi Novae”, vol. 5, s. 57-85.

2000b Przemiany kulturowe zwiqzane z procesem formowania się państwa Piastów, Poznań (maszynopis pracy doktorskiej w archiwum IAE PAN).

2000c Stan badań dendrochronologicznych wczesnosiredniowiecznych grodzisk z terenu Wielkopolski [Sum. The current state of dendrochronological dating of the early medieval strongholds of Wielkopolska (1990-1999)], (w:) Osadnictwo i architektura ziem polskich w dobie Zjazdu Gnieźnieńskiego (red. A. Buko, Z. Świechowski), Warszawa, s. 55-68.

Kara M., Krapiec M.

2000 Możliwości datowania metodą dendrochronologiczna oraz stan badań dendrochronologicznych wczesnośredniowiecznych grodzisk z terenu Wielkopolski, Dolnego Ślqska i Małopolski, (w:) Ziemie polskie $w X$ wieku i ich znaczenie w ksztaltowaniu się nowej mapy Europy (red. H. Samsonowicz), Kraków, s. 303-327.

Krause E.

1976 Grodzisko stożkowate w Bninie koto Śremu [Zus. Turmhügel (Motte) in Bnin neben Śrem], (w:) Materialy do studiów nad osadnictwem bnińskim. Grodzisko stożkowate (red. J. Żak), Warszawa - Poznań, s. 3-115. 
Krąpiec $M$.

1998a Dendrochronological dating of early medieval fortified settlements in Poland, (w:) Friihmittelalterlicher Burgenbau in Mittel- und Osteuropa (red. J. Henning, A.T. Ruttkay), Bonn, s. 257-266.

1998b Oak dendrochronology' of the Neoholocene in Poland, „Folia Quaternaria”, t. 69, s. 5-133.

Kurnatowska Z.

1998 Forschungen zu frühmittelalterlichen Burgen in Großpolen, (w:) Frühmittelalterlicher Burgenbau in Mittel- und Osteuropa (red. J. Henning, A.T. Ruttkay), Bonn, s. 31-36.

Kurnatowska Z., Łosińska A.

1990 Stan i potrzeby badań nad wczesnym średniowieczem w Wielkopolsce, (w:) Stan i potrzeby badań nad wczesnym średniowieczem w Polsce (red. Z. Kurnatowska), Poznań - Wrocław Warszawa, s. 105-153.

Leśny J.

1976 Poczqtki, rozwój i upadek kasztelanii na Ostrowie Lednickim, „Studia i Materiały do Dziejów Wielkopolski i Pomorza", t. XII (23), z. 1, s. 5-37.

Łos ińs k i W.

1990 Stan i potrzeby badań nad wczesnym średniowieczem na Pomorzu Zachodnim. (w:) Stan i potrzeby badań nad wczesnym średniowieczem w Polsce (red. Z. Kurnatowska), Poznań Wrocław - Warszawa, s. 23-49.

Ossowski W.

1999 Studia nad lodziami jednopiennymi z obszaru Polski [Sum. Study on logboats from Poland]. Gdańsk.

Ossowski W., Krąpiec M.

1999 Problemy datowania bezwzględnego najstarszych zabytków szkuıniczych z teremu Polski metoda dendrochronologiczna [Sum. Problems of absolute dendrochronological dating of the oldest boatbuilding relicts from Poland], „Przegląd Archeologiczny”, t. 47, s. 155-165.

Pałubicka A.

1975 Grodzisko wklęste w Bninie, pow. śremski [Zus. Niederungsburg in Bnin, Kreis Śrem], (w:) Materialy do studiów nad osadnictwem bnińskim. Grodzisko wklęste (red. J. Żak), Poznań. s. 11-184.

Szamałek K., Dudzia k-Jankowiakowa J., Karolczak Z.

1979 Osadnictwo podgrodzia bnińskiego [Zus. Besiedlung der Vorburg in Bnin], (w:) Materiaty do studiów nad osadnictwem bnińskim. Podgrodzie (red. J. Żak), Warszawa - Poznań, s. 5-263.

$\dot{\mathrm{Z}}$ a k J.

1986 Bnin, (w:) Słownik Starożytności Słowiańskich, t. 7, cz. 2, Wrocław - Warszawa - Kraków - Gdańsk - Łódź, s. 488, 489.

Ż a k J., Fo ge l J. (red.)

1985 Materiaty do studiów nad osadnictwem bnińskim. Mikroregion bniński, Poznań.

\section{FRÜHMITTELALTERLICHE BURGWALLANLAGE IN BNIN BEI POSEN IM LICHTE BISHERIGER DENDROCHRONOLOGISCHER FESTLEGUNGEN}

\section{Zusammenfas sung}

Im Artikel wurden die Ergebnisse der dendrochronologischen Untersuchungen der Holzkonstruktionen des frühmittelalterlichen Walls auf der Burgwallanlage in Bnin (jetzt Kórnik-Bnin dargestellt), Fst. 2a, Woi. Wielkopolska (Großpolen), gelegen im Zentralteil der Halbinsel „Szyja” („Hals”) des 
Bnińskie Sees, ca. 25 km südöstlich von Posen. Das Objekt hat in den Jahren 1961-1969, mittels Ausgrabungen, die Expedition von J. Żak, die ab 1964 im Rahmen des Lehrstuhls für Polnische und Allgemeine Archäologie bei der Universität zu Posen tätig war, untersucht. Die Ergebnisse wurden in einer musterhaft vorbereiteten Monographie der Fundstelle (Pałubicka 1975) veröffentlicht. Synthetisch wurden sie im Stownik Starożytności Stowiańskich (Żak 1986) besprochen.

Die dendrochronologischen Analysen wurden durchgeführt im Rahmen eines Verifikationsprogrammes für die Datierung der mittelalterlichen, großpolnischen Burgwälle, deren Entstehungszeit (vor allem im letzten halben Jahrhundert) auf Grund einer stratigraphischen und/oder Vergleichs- und typologischen Analyse der Funde festgelegt wurde. In der ersten Reihe wurden Objekte von besonderer Bedeutung für die Periodisierung des frühen Mittelalters in Großpolen ausgewählt. Die Aktion wurde in den Jahren 1990-1992 aus Initiative des Instituts für Archäologie und Ethnologie bei der Polnischen Akademie der Wissenschaften - Abteilung in Posen durchgeführt.

Beim Burgwall in Bnin wurden für die dendrochronologischen Untersuchungen die äußeren, von der Expedition J. Żaks in den Jahren 1967-1968 auf dem Ar 268A-B in der sogenannten „nördlichen” Grabungsfläche freigelegten Randabschnitte des Holz-Erdwalls bestimmt. Für eine solche Wahl sprachen die technischen Gründe, vor allem die verhältnismäßig geringe Tiefe, in der sich die Konstruktion befand, und die einen straffen Verlauf der Geländeuntersuchungen suggerierte, sowie der mit der Dokumentation bestätigte, ausgezeichnete Erhaltungszustand des Eichenholzes wie auch Zweiphasenrelikte und die Tatsache, daß sie nach Meinung der Entdecker die äußere Böschung von Festungen bestimmten, die mit Burgen verbunden waren, welche in schriftlichen Quellen aus dem 13. Jh. erwähnt sind.

Die Verifikations- und Sondierungsuntersuchungen wurden vom 12.-25. Oktober 1994 durchgeführt. Es wurden drei Sondierungsgrabungen ausgeführt; die dendrochronologischen Proben (28 Stück, darin 25 datiert) wurden aus zwei, mit Nummern I. und II./1994 gekennzeichneten Grabungsflächen entnommen. Die erste wurde im südlichen Teil der Grabungsfläche von J. Żak lokalisiert, wobei der westliche Rand der Sondierung eine Erweiterung der genannten Grabungsfläche war; die zweite wurde auf dem Vorfeld des Burgwalls, direkt am Rand der Wallaufschüttung plaziert. Die „Erweiterung” der Grabungsfläche aus den Jahren 1967-1968 mit den bisher nicht untersuchten Partien war notwendig, weil die damals freigelegten Holzkonstruktionen den beschleunigten Fäulnisprozessen infolge des grôBeren Zutritts von Luft zweifellos ausgesetzt waren.

Es wurden Ausschnitte aus einem Wallskelett aus Holz freigelegt, die insgesamt aus drei Reihen mit Sand bestreuten Stapeln, bestehend aus Eichenbalken, -langhölzern und -halbrundhölzern, gebaut waren. Es wurde festgelegt, daß sich die einzelnen Reihen - abgesondert als Schichten Nr. Va, IIla und Ila (Abb. 2) - aufeinander ringförmig überlagerten; die äußere Reihe lehnte sich an die Flucht der früheren Anlage. Ihre Konstruktion, Baumaterial und stratigraphische Lage waren identisch wie bei den in den Jahren 1967-1968 freigelegten Relikten.

Die erhaltenen Holzproben wurden an Herrn Dr. M. Krapiec aus der Dendrochronologischen Werkstatt bei der Berg- und Hüttenakademie in Krakau zur Analyse übergeben. Zur Überraschung der Archäologen haben die erhaltenen Ergebnisse ein anderes Bild als das von den Archăologen gebracht. Es ist hinzuzufügen, da $B$ die Datierung des Siedlungskomplexes von Bnin bisher keine Kontroversen erweckte und die für bewegliches Material (vor allem Gefaßkeramik) getroffenen Festlegungen betreffs Entstehungsdatum mehrmals ein Bezugspunkt bei den Studien über die Chronologie anderer großpolnischer Burgwälle waren.

Es wurde festgestellt, daß die inneren Stapel, die zur Schicht Nr. Va gezählt wurden, aus den zwischen AD 934 und 938 gefältten Eichen gestapelt, und die aüßeren Stapel, die in der Schicht Nr. IIIa gefunden sind, aus den im Jahre 940 gefälten Eichen konstruiert wurden, wobei dort das in den Jahren 935 und 939 gesammelte Baumaterial sporadisch ausgenutzt war. Nach Festlegungen von A. Pałubicka stammten die genannten Wallkonstruktionen aus der Wende des 12. und Anfang des 13. Jhs. 
Das Festungswerk wurde erneuert, indem von der Front eine neue Stapelreihe in einer bei der Unterschwelle mit quer gelegten Hakenbalken zusammengebundenen Gitterkonstruktion zugestellt wurden. Diese Stapelsequenzen wurden als Schicht Nr. IIa abgesondert; vielleicht bestimmten sie die aüßere Wallberme (Abb. 2). Es wurde die Zeit des Abhiebs von zwei Eichen bestimmt, aus den die Halbrundholzer zur Auslegung der Konstruktionssohle ausgeführt wurden: nach AD 947 und nach AD 957. Die Stapel Nr. Ila datierte A. Pałubicka in das 2. Viertel des 13. und Anfang der 2. Hälfte des 13. Jhs.

Aus der Verteilung der Dendrodaten erfolgt, daß der freigelegte Teil des Walls in Bnin in zwei Etappen, mit einer Pause im Jahre 939, errichtet wurde. Die ältere Etappe wurde AD 938 beendet; höchstwahrscheinlich wurde sie um das Jahr 934 begonnen, eventuell begann man in dieser Zeit mit der Sammlung des Baumaterials. Die jüngere Etappe wurde dagegen AD 940 beendet. Dabei wurden u.a. die Langhölzer aus den im vorhergehenden Jahr gefüllten Bäumen ausgenutzt. Da sich die Lokalisierung der Proben nur auf den aüßeren Wallabschnitt einschränkt, kann man nicht entscheiden, ob im Jahre 934 mit dem Bau der Burg begonnen oder ob in diesem Jahr eine fortgeschrittene Renovierung der schon bestehenden Anlage durchgeführt wurde.

Eine große Anzahl von Proben und der geschlossene Charakter der Bestimmungen schließen einen Fehler der Dendrochronologie aus. Wir möchten notieren, daß die erhaltenen Dendrodaten die Festung in Bnin in den Horizont großpolnischer Burgen einschreibt, die in den Jahren um 935-940/945 erbaut wurden, was die dendrochronologischen Analysen der Holzkonstruktionen der Wälle nachgewiesen haben. In dieser Zeit wurden unter anderen die Festungen auf dem Lechberg in Gnesen, in GrzybowoRabieżyce, Giecz und Ląd errichtet, wobei in den drei letzten Fällen gründliche Renovierung der älteren Anlagen erfolgte. Die genannten Burgwälle (mit Ausnahme von Ląd) liegen in der Nähe von Bnin.

Es besteht also kein Zweifel, daß der Kreis der Posener Archäologen- Mediävisten vor die Notwendigkeit der Aufnahme von Untersuchungen gestellt wurde, die die Chronologie des Siedlungskomplexes in Bnin verifizieren würden. 